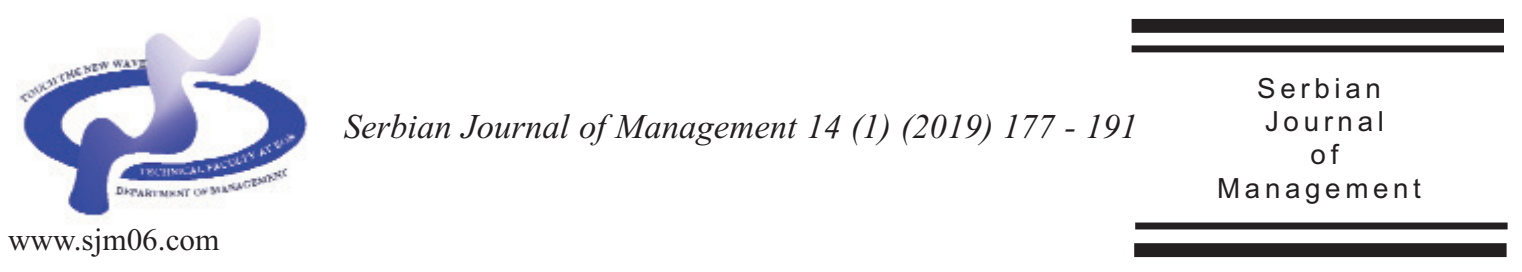

\title{
CONTINUOUS IMPROVEMENT AND ORGANIZATIONAL PRACTICES IN SERVICE FIRMS: EXPLORING IMPACT ON COST REDUCTION
}

\author{
Oksana Koval $^{\mathbf{a}^{*}}$, Stephen Nabareseh ${ }^{\mathrm{b}}$, Roland Stankalla ${ }^{\mathrm{a}}$ and \\ Felicita Chromjakova ${ }^{a}$ \\ a Tomas Bata University, Faculty of Management and Economics, \\ Department of Industrial Engineering and Information Systems, \\ nám. T. G. Masaryka 5555, 76001 Zlín, Czech Republic

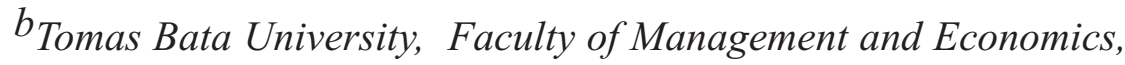 \\ Department of Statistics and Quantitative Methods, \\ nám. T. G. Masaryka 5555, 76001 Zlín, Czech Republic
}

(Recedived 14 March 2018; accepted 11 October 2018)

\begin{abstract}
A growing importance of services sectors for global trade invokes the question of how to combat the innate complexity and inefficiency of service operations. As a response to the growing request for enhancement of service efficiency, companies implement Continuous Improvement (CI) initiatives to reduce costs of operations. However, the researchers failed to reach consensus on the effect of CI operations efficiency in non-manufacturing environment. Thus, the proposed study attempts to answer an important question of impact of CI on cost reduction in the services environment by applying Structural Equation Modeling to the 304 survey responses collected in the course of the study. Furthermore, the research investigates how organizational practices impact relationship between CI and cost reduction. The study suggests that CI itself is unable to reduce costs and requires a support of multiple organizational practices, such as Rewards and Recognition of Employees, Quality Culture, Employee Training and Goal setting, to obtain the benefits of cost reduction. Consequently, the research results allow for a conclusion with a vast practical implication that there is need to develop a comprehensive infrastructure of organizational practices to support CI in order to attain cost reduction. The research findings provide recommendations for CI implementation and investment prioritization in service organizations.
\end{abstract}

Keywords: continuous improvement, service companies, cost reduction, SEM, V4 countries

\footnotetext{
* Corresponding author: koval@utb.cz
}

DOI: $10.5937 /$ sjm14-16840 


\section{INTRODUCTION}

Due to the growing pressure on profit margins, service companies are forced to develop new approaches to productivity and implement $\mathrm{CI}$ as a way to reduce operational costs (Milner \& Savage, 2016). Cost reduction serves as a major driver for introduction of $\mathrm{CI}$ in service companies despite of the considerably limited research on $\mathrm{CI}$ in the non-manufacturing field. In conjunction with the lack of established conclusion on the effect of $\mathrm{CI}$ on cost reduction, there is even less research on the impact of organizational practices on CI Cost Reduction relationship, in spite of the evidence of the ability of organizational practices to foster cost reduction persists (Rust et al., 2002; Piercy \& Rich, 2009).

In order to address the identified knowledge gaps, the proposed study is set to fulfil the following research objectives: 1) to evaluate impact of $\mathrm{CI}$ on cost reduction in the services environment, and 2) to assess the level to which organizational practices are able to distort or promote CI - Cost Reduction relationship. Structural Equation Modeling (SEM) is applied to study the relationship between CI, cost reduction and selected organizational practices on the set of 304 service companies from the Visegrad region. The study provides insights on the impact of $\mathrm{CI}$ on cost reduction and then investigates the role of the organizational practices in performance of $\mathrm{CI}$ the services setting.

\section{THEORETICAL FRAMEWORK}

Complexity and variety of service processes, needed to meet changing customer needs, causes excessive waiting times and high level of non-value-added activities leading to increased production costs. in response to the variety of customer requirements and to ensure quality, efficiency and flexibility organizations apply CI. Publications on implementation of $\mathrm{CI}$ in the non-manufacturing industries are focused to a great extent on healthcare (George, 2003; Graban \& Swartz, 2012; McFadden et al., 2014; D'Andreamatteo et al., 2015) and financial services (Hendricks \& Singhal, 2001; Williams, 2006; Delgado et al., 2010).

The limited research on operations improvement in services, and especially, non-routine ones, can be explained by the challenging application of CI to the nonmanufacturing processes. Since Cost Reduction is considered as one of the main motives for introduction of $\mathrm{CI}$ initiatives in the companies, the proposed research is set to fill in the research gap by assessing impact of CI on Cost Reduction, and further explore whether organizational practices are able to facilitate CI - Cost Reduction relationship in the services setting.

\subsection{Soft and Hard Organizational Practices}

The proposed research builds upon current academic literature that emphasizes the multilevel model of soft and hard practices and their contribution to the overall performance of $\mathrm{CI}$ in the firms. Following Shah and Goldstein (2006) we develop a priori model with multiple mediators (Figure 1). The priori model has been adapted from the previous research on evaluation of $\mathrm{CI}$ impact in empirical studies (Powell 1995; Peng et al. 2008; Taylor et al. 2013, among others). The priori model is built upon assumptions of the positive impact of $\mathrm{CI}$ on Cost Reduction and the underlying 
assumption of the positive impact of soft practices (Quality Culture, Management Commitment, and Rewards and Recognition for employees) as well as hard practices (Employee Training and Goal Setting) on CI - Cost Reduction relationship.

Quality culture is one of the hallmark developments within organizations, engaging in CI. Implementation of CI boosts development of quality-oriented culture, which means that employees and departments of the organization focus on delivering better quality of the product or service. We conceptualize this mediator based on Bortolotti et al. (2015) and Jayanth and $\mathrm{Xu}$ (2016). Training in improvement methods can significantly impact performance in $\mathrm{CI}$; thus, we include training

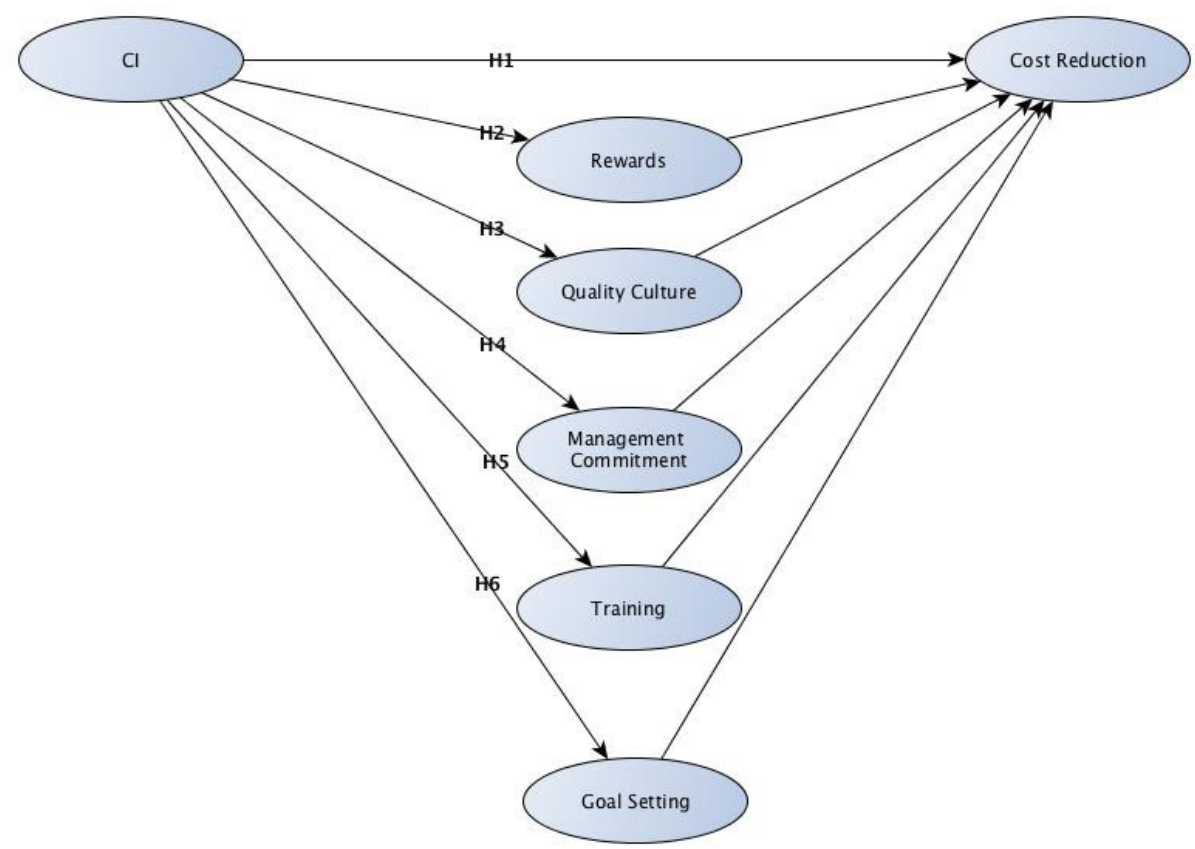

Figure 1. Priori model of CI - Cost Reduction relationship

Table 1. Justification of Research Hypotheses

\begin{tabular}{|c|c|c|}
\hline Number & Research Hypothesis & Supporting References \\
\hline $\mathbf{H}_{1}$ & $\begin{array}{l}\text { Increase in the level of CI in the company induces higher } \\
\text { Cost Reduction. }\end{array}$ & $\begin{array}{l}\text { Deming, (1993); Prajogo \& Brown, (2006); } \\
\text { Sila, (2007); Jurburg et al., (2015); Romero et } \\
\text { al., (2015) }\end{array}$ \\
\hline $\mathbf{H}_{2}$ & $\begin{array}{l}\text { The Rewards and Recognition system stimulating } \\
\text { participation in improvement initiative promotes the } \\
\text { relationship between CI and Cost Reduction. }\end{array}$ & $\begin{array}{l}\text { Sabella et al., (2014); Yang et al., (2014); } \\
\text { Habtoor, (2016) }\end{array}$ \\
\hline $\mathbf{H}_{3}$ & $\begin{array}{l}\text { Quality culture promotes the relationship between CI and } \\
\text { Cost Reduction. }\end{array}$ & $\begin{array}{l}\text { Detert et al. (2000); Bortolotti et al. (2015); } \\
\text { Jayanth and Xu (2016) }\end{array}$ \\
\hline $\mathbf{H}_{4}$ & $\begin{array}{l}\text { Commitment of management to improvement initiative } \\
\text { facilitates the relationship between CI and Cost } \\
\text { Reduction. }\end{array}$ & $\begin{array}{l}\text { Anand et al., (2012); Swartling \& Poksinska, } \\
\text { (2013); Habtoor, (2016) }\end{array}$ \\
\hline $\mathbf{H}_{5}$ & $\begin{array}{l}\text { Employee training in the improvement technique } \\
\text { facilitates the relationship between CI and Cost } \\
\text { Reduction. }\end{array}$ & $\begin{array}{l}\text { Hietschold et al., (2014); Habtoor, (2016); } \\
\text { Jayanth \& Xu, (2016) }\end{array}$ \\
\hline $\mathbf{H}_{6}$ & $\begin{array}{l}\text { Goal setting promotes the relationship between CI and } \\
\text { Cost Reduction. }\end{array}$ & $\begin{array}{l}\text { Galeazzo et al., (2016); Kaynak, (2003); } \\
\text { Sabella et al., (2014) }\end{array}$ \\
\hline
\end{tabular}


as a mediator in the model (Hietschold et al., 2014; Habtoor, 2016; Jayanth \& Xu, 2016). Management commitment to CI program is an important prerequisite for "buy in" of the changes, caused by CI from multiple stakeholders and can significantly impact effectiveness of CI. Management commitment mediator was adapted from Anand et al. (2012), Swartling and Poksinska (2013) and Habtoor (2016). Researchers assert the need to engage personnel in CI through design of the appropriate rewards and recognition system for employees that participate in CI projects (Sabella et al., 2014; Yang et al., 2014; Habtoor, 2016). To ensure strategic alignment of $\mathrm{CI}$ and its ability to achieve declared goals, it is important to develop a system of goals for the improvement initiative (Kaynak, 2003; Sabella et al., 2014; Galeazzo et al., 2016). The latent variable of CI is evaluated in three dimensions: the company's strive for quality improvement (operationalized from Prajogo and Brown (2006), Sila (2007), and Näslund (2013)) and on-going elimination of nonvalue added activities (from Deming (1993) and Jurburg et al., (2015)) as well as process standardization (from Pellicer et al., (2012) and Romero et al. (2015)).

\section{METHODOLOGY}

As a first step in our research, the priori model based on the proposed hypotheses was established (Figure 1). Following methodological recommendations by Baron and Kenny (1986) and Iacobucci et al. (2007), the research applies Structural Equation Modeling (SEM) to establish validity of the priori model.

The data for SEM analysis was collected through the survey. The survey items were scrutinized from the similar previous studies on CI application and further adapted to suit investigation in the services environment (see Table 1). To evaluate impact of CI on cost reduction and evaluate the importance of selected mediators, the study employs a 15 Liker-type scale. The survey items serve as the observed variables and as a proxy to measurement of the priori latent variables, namely Continuous Improvement (CI) and Cost Reduction (CR).

Prior to launching a large-scale study, the survey tool was validated through the discussion of the survey with the two researchers and two senior consultants experienced in conducting survey-based studies in the service domain. This step is essential in ensuring suitability of the instrument for the selected research objectives.

\subsection{Collection of data and description of the sample}

The research focused on the four countries in the Visegrad region: Poland, Hungary, Czech Republic and Slovak Republic. In order to identify the initial contacts within the target companies, the contacts were extracted from the databases provided by the national investment and development agencies. The research sample was further expanded by applying the snowballing technique suggested by Edmondson and McManus (2007). In total, 950 surveys were sent out and 352 surveys were returned, out of which 304 surveys were selected because some of the surveys were returned incomplete. The final response rate accounted for $32 \%$.

The final sample is represented by 304 respondents from 304 companies. To ensure representability of the results, service 
companies from the different industries were selected (Table 2). The priori model includes mediating and latent variables to decipher a clearer picture of the hypothesized relationships. Table 3 provides further details on distribution of the responses per selected variables.

Table 2. Research sample

\begin{tabular}{lcccc}
\hline $\begin{array}{l}\text { Branch of the } \\
\text { respondent's company }\end{array}$ & Poland & $\begin{array}{l}\text { Slovak } \\
\text { Republic }\end{array}$ & $\begin{array}{l}\text { Czech } \\
\text { Republic }\end{array}$ & Hungary \\
\hline Finance & 14 & 6 & 17 & 12 \\
Accounting & 15 & 5 & 16 & 15 \\
Human Resources & 14 & 5 & 12 & 9 \\
Logistics & 17 & 3 & 10 & 7 \\
Information Technology & 15 & 5 & 15 & 10 \\
Customer Support & 13 & 5 & 18 & 19 \\
Procurement & 8 & 3 & 9 & 7 \\
Total & 96 & 32 & 97 & 79 \\
\hline
\end{tabular}

Table 3. Distribution of responses per selected variable

\begin{tabular}{|c|c|c|}
\hline Survey Item & Variable & $\begin{array}{l}\text { Percentage of } \\
\text { respondents who } \\
\text { responded positively to } \\
\text { the question }\end{array}$ \\
\hline \multicolumn{3}{|l|}{ Continuous Improvement (CI) Items } \\
\hline $\begin{array}{l}\text { We tend to remove non-value added activities from the } \\
\text { processes }\end{array}$ & CI1 & $86.5 \%$ \\
\hline We tend to standardize processes between served clients & $\mathrm{CI} 2$ & $70.5 \%$ \\
\hline $\begin{array}{l}\text { We strive for quality improvement and have an } \\
\text { improvement program in place }\end{array}$ & $\mathrm{CI} 3$ & $60.9 \%$ \\
\hline \multicolumn{3}{|l|}{ Mediator Items } \\
\hline $\begin{array}{l}\text { Our company has established an effective recognition and } \\
\text { reward system to stimulate employee participation in CI } \\
\text { program }\end{array}$ & $\mathrm{C} 1$ & $58.1 \%$ \\
\hline $\begin{array}{l}\text { Our company has a strong corporate culture oriented on } \\
\text { quality and supports associated cultural changes }\end{array}$ & $\mathrm{C} 2$ & $67.3 \%$ \\
\hline $\begin{array}{l}\text { Management of the company shows a strong commitment } \\
\text { to CI through regular communication about CI, } \\
\text { participation in the improvement events and visible support } \\
\text { to the CI program }\end{array}$ & $\mathrm{C} 3$ & $64.9 \%$ \\
\hline $\begin{array}{l}\text { Our company ensures that employees, participating in CI } \\
\text { projects, received proper training and learning } \\
\text { opportunities }\end{array}$ & $\mathrm{C} 4$ & $30.6 \%$ \\
\hline $\begin{array}{l}\text { Our company sets goals and improvement projects that } \\
\text { focus on customer needs }\end{array}$ & C5 & $87 \%$ \\
\hline
\end{tabular}


Mediators with an alpha greater than the test statistic of 0.7 , are constant, stable and reliable. If the alpha is greater or nearer to 1 , then the greater the dependability and consistency of the measured variable. Viewing from Table 4, alpha of CI is 0.900 while mediators had 0.768 , it confirms that constancy, stability and reliability of variable components are definite for further analysis.

\subsection{Exploratory Factor Analysis}

Exploratory Factor Analysis (EFA) was done in data analytics to abridge data, construe the level at which variables converge, develop hypotheses for further analysis and help shorten data dimensions. According to Hair et al., (1998) and by rule of thumb, variables in a factor analysis that produce loadings more than $0.30,0.40$ and 0.50 are categorised as quite important, important and very important respectively. For the purpose of further analysis, variable loadings of 0.50 or more are considered. In line with the above, the paper relied on 0.50 or more variable loadings in doing the Path analysis. However, the test of appropriateness of EFA on the data was first

Table 4. Reliability statistics

\begin{tabular}{lccc}
\hline \multicolumn{1}{c}{ Construct } & Cronbach's Alpha $(\boldsymbol{\alpha})$ & $\boldsymbol{\alpha}$ Based on Standardized Items & N of Items \\
\hline CI & 0.900 & 0.910 & 3 \\
Mediators & 0.768 & 0.834 & 5 \\
\hline
\end{tabular}

Table 5. Total variance explained

\begin{tabular}{|c|c|c|c|c|c|}
\hline \multirow[t]{2}{*}{ Survey Items } & \multicolumn{3}{|c|}{ Initial Eigenvalues } & \multicolumn{2}{|c|}{ Extraction Sums of Squared Loadings } \\
\hline & Total & $\%$ of Variance & Cumulative \% & Total \% of Variance & Cumulative \% \\
\hline \multicolumn{6}{|c|}{ Continuous Improvement } \\
\hline CI1 & 1.763 & 45.234 & 45.234 & 1.76345 .234 & 45.234 \\
\hline $\mathrm{CI} 2$ & 1.365 & 30.556 & 75.790 & 1.36530 .556 & 75.790 \\
\hline $\mathrm{CI} 3$ & 1.003 & 24.210 & 100.00 & & \\
\hline \multicolumn{6}{|c|}{ Mediators } \\
\hline $\mathrm{C} 1$ & 1.384 & 40.180 & 40.180 & 1.38440 .180 & 40.180 \\
\hline $\mathrm{C} 2$ & 1.261 & 31.150 & 71.330 & 1.26131 .150 & 71.330 \\
\hline $\mathrm{C} 3$ & 1.075 & 18.011 & 89.341 & 1.07518 .011 & 89.341 \\
\hline $\mathrm{C} 4$ & 0.920 & 7.920 & 97.261 & 0.9207 .920 & 97.261 \\
\hline C5 & 0.543 & 2.739 & 100.0 & & \\
\hline \multicolumn{6}{|c|}{ Kaiser-Meyer-Olkin Measure of Sampling Adequacy (KMO) and Bartlett's Test } \\
\hline KMO & & & & & 0.769 \\
\hline \multirow{3}{*}{\multicolumn{3}{|c|}{ Bartlett's Test of Sphericity }} & & Approx. $\chi^{2}$ & 2836.024 \\
\hline & & & & $\mathrm{df}$ & 91 \\
\hline & & & & Sig. & 0.000 \\
\hline
\end{tabular}

Extraction Method: Principal Component Analysis. 
carried out with the Kaiser-Meyer-Olkin (KMO) sample adequacy measurement and the test of the correlation matrix to determine the existence of identity matrix using Bartlett's Test of Sphericity (BTS). The results indicate that BTS is very significant $(P=0.00)$, correlation of variables is 0.30 or above and the sample is also adequate (KMO $=0.769$ ).

The eigenvalues were produced using the Principal Component Analysis (PCA). By rule of thumb, eigenvalues whose total factor loadings are 1 or above are always recommended to be considered for further analysis. Research has also generalised that where measurement variables are less, loadings nearer to 1 may also be used. This paper therefore added loadings closer to 1 for further analysis due to the smaller number of variables. The first two measurement variables in CI explained $75.79 \%$ of variance. All the three variables had total loadings more than 1. Conversely three variables explained $89.34 \%$ of variance in line with the mediator variables (see Table 5). Convergent and discriminant validity were satisfied in loadings more than 0.50 .

\section{Table 6. Correlations of Latent Variables} and Outcome

\begin{tabular}{llll}
\hline \multirow{2}{*}{ Latent Variables } & \multicolumn{3}{c}{ CI } \\
& $\mathrm{CI} 1$ & $\mathrm{CI} 2$ & $\mathrm{CI} 3$ \\
\hline Cost reduction & $0.343^{*}$ & $0.500^{*}$ & 0.134 \\
$P$-Value & 0.000 & 0.000 & 0.051 \\
\hline
\end{tabular}

Note: *Correlation is significant at 0.05 levels (two tailed)

\subsection{SEM Model Reliability and Validity}

The data produced a priori model as indicated in Fig.1. From Table 6, the three variables (CI1, CI2, C13) have a very high positive correlation with Cost Reduction (CR). For constancy and stability, the test of convergence was applied. To authenticate convergence of latent variables, Average Variance Extracted (AVE) was applied. The Fornell-Lacker Criterion Discriminant Validity Test, in applying the square root of AVE, resulted in a diagonal value of 0.74 , as a confirmation of the models discriminant validity. The values in Table 7 are measurement variables with more than 0.5 threshold values.

\subsection{Testing Hypotheses for Cost Reduction Model}

To clarify impact of CI on Cost Reduction, six research hypotheses were elicited to develop a priori model. Further, null hypotheses $\left(\mathrm{H}_{\mathrm{on}, \mathrm{n}=1 \ldots 6}\right)$ were established with the purpose of testing whether the research hypotheses are supported (Table 8). The significance level of 0.05 was established for null hypothesis testing. Based on the testing of null hypotheses, the analysis demonstrates that research hypotheses $\mathrm{H} 2, \mathrm{H} 3, \mathrm{H} 5$ and $\mathrm{H} 6$ are supported by the results with p-values less than the test statistic of 0.05 .

To evaluate impact of selected organizational practices on CI - Cost

Table 7. Quality Criteria for the latent variable of Continuous Improvement used in SEM

\begin{tabular}{lccccc}
\hline Symbols & Bootstrapped T-Value (loadings) & Loadings & CR & $\boldsymbol{\alpha}$ & AVE \\
\hline CI1 & 4.268 & 0.867 & & & \\
CI2 & 4.043 & 0.769 & 0.866 & 0.900 & 0.577 \\
CI3 & 3.432 & 0.733 & & & \\
\hline
\end{tabular}


Reduction relationship, a Structural Equation Model (SEM) was developed. Table 9 and Figure 2 summarize the results of SEM. The model in Figure 2 has three latent variables for CI, five for the Mediators, and the outcome variable of Cost Reduction, denoted as D2. The model has a good fit since the results in the fit analysis in Table 8 meet the criteria for assessing fitness. The model fit results in Table 8 indicate a non-significant chi-square, An RMSEA $<0.05$ and a CFI of 0.930 , which is closer to 1 . From Figure 2 and Table 8, the mediators that influence Cost Reduction are clearly seen in the results of the hypotheses.

Further, the comparison of the coefficients for the model paths provide evidence for evaluation of the effect of mediating variables on the CI - Cost Reduction relationship. The positive effect of the mediating variable can be established if the path coefficient with a studied mediating variable is larger than the coefficient for a base path (the direct relationship between CI and CR). The results demonstrate that CI has no direct positive impact on Cost Reduction, demonstrated by coefficient of 0.079 . The results indicate that $\mathrm{CI}$ itself does not improve Cost Reduction without certain form of influence from mediators. In addition, $\mathrm{H} 4$ is also not supported suggesting that Management Commitment does not

Table 8. Null Hypotheses Testing

\begin{tabular}{|c|c|c|c|c|}
\hline Number & Null Hypothesis & P-value & Statistics & Outcom \\
\hline $\mathbf{H}_{01}$ & $\begin{array}{l}\text { Increase in the level of CI in the company does not induce higher Cost } \\
\text { Reduction. }\end{array}$ & 0.422 & 2.581 & Accepte \\
\hline $\mathbf{H}_{02}$ & $\begin{array}{l}\text { The Rewards and Recognition system stimulating participation in } \\
\text { improvement initiative does not promote the relationship between CI and } \\
\text { Cost Reduction. }\end{array}$ & 0.000 & 2.660 & Reject \\
\hline $\mathbf{H}_{03}$ & $\begin{array}{l}\text { Quality culture does not facilitate the relationship between CI and Cost } \\
\text { Reduction. }\end{array}$ & 0.001 & 3.651 & Reject \\
\hline $\mathbf{H}_{04}$ & $\begin{array}{l}\text { Commitment of management to improvement initiative does not facilitate } \\
\text { the relationship between CI and Cost Reduction. }\end{array}$ & 0.212 & 2.376 & Accept \\
\hline $\mathbf{H}_{05}$ & $\begin{array}{l}\text { Employee training in the improvement techniques does not facilitate the } \\
\text { relationship between CI and Cost Reduction. }\end{array}$ & 0.000 & 2.471 & Reject \\
\hline $\mathbf{H}_{06}$ & $\begin{array}{l}\text { Goal setting does not promote the relationship between CI and Cost } \\
\text { Reduction. }\end{array}$ & 0.043 & 3.550 & Reject \\
\hline
\end{tabular}

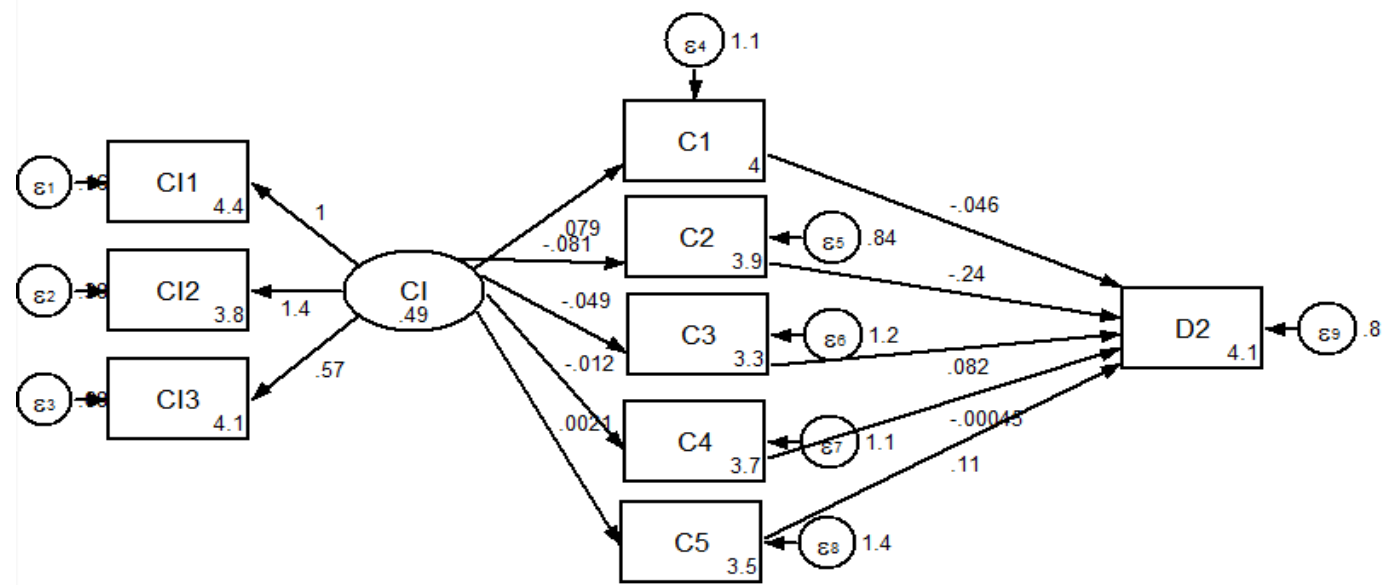

Figure 2. Estimated model of CI - Cost Reduction (CR) relationship 
Table 9. Evaluation of Impact of mediators on CI-Cost Reduction relationship

\begin{tabular}{lccc}
\hline \multicolumn{1}{c}{ Model Path } & Coefficient & S.E. & Impact on CI - Cost Reduction \\
\hline CI -> CR & 0.079 & 0.098 & Neutral \\
CI $->$ Rewards -> CR & 0.341 & 0.045 & Positive \\
CI -> Quality culture -> CR & 0.239 & 0.075 & Positive \\
CI -> Management commitment $->$ CR & -0.082 & 0.066 & Negative \\
CI -> Employee training -> CR & 0.229 & 0.052 & Positive \\
CI -> Goal setting -> CR & 0.112 & 0.057 & Positive \\
FIT INDICES Chi2 $=873.070 ;$ P>chi $=0.053 ; \mathrm{R}^{2}=0.965 ; \mathrm{RMSEA}=0.041 ; \mathrm{df}=304 ; \mathrm{CFI}=0.930$ \\
\hline
\end{tabular}

impact Cost Reduction. Furthermore, the negative coefficient in Table 8 indicates the potential adverse effect of Management Commitment on CI - Cost Reduction relationship. Valid Statistical figures support the results in Table 8.

\section{DISCUSSION}

Cost Reduction is considered as one of the main motives for introduction of $\mathrm{CI}$ initiatives in the companies (Ashkenas, 2012) and our findings demonstrate that CI without the supporting practices is not able to deliver cost reduction. This is a surprising finding, taking into account previous research suggesting otherwise ( Rust et al., 2002; Piercy \& Rich, 2009; Paagman et al., 2015). However, as the research demonstrates, Cost Reduction may be achieved, when in addition to $\mathrm{CI}$, a supporting organizational infrastructure in the form of practices is implemented. The analysis demonstrates that $\mathrm{CI}-$ Cost Reduction relationship can be positively impacted by the following organizational practices: Rewards and Recognition of Employees, Quality Culture, Employee Training and Goal setting. Consequently, our study confirms previous studies on the organizational practices facilitating cost reduction in the CI process (Anand et al., 2012; Bortolotti et al., 2015; Habtoor, 2016).
This is an important finding that could partially explain the differences in the results of the previous studies trying to assess impact of CI on cost reduction, since the relationship could be drastically impacted by supporting practices (Prajogo \& Brown, 2006; Jurburg et al., 2015; Romero et al., 2015 among others).

While the study confirms positive impact of four selected practices on CI - Cost reduction relationship, the study demonstrates that management commitment may have a negative impact on the cost reduction efforts. These findings provide an interesting case for further scholarly work, since previous studies largely support the high importance of management commitment in ensuring effectiveness of CI (Liker \& Morgan, 2006; Chakravorty, 2009; Bon \& Mustafa, 2013; Näslund, 2013; Swartling and Poksinska, 2013; Dubey et al., 2015). Since management commitment may negatively affect CI - Cost Reduction, further research is needed to explore the possibilities of management involvement in the CI initiative for achievement of cost reduction.

Goal-setting for improvement projects was found to have a positive impact on CIcost reduction relationship which provides an interesting perspective on the issues of motivation in human resource literature. Further research is needed to explore the effect of $\mathrm{CI}$ on the employee motivation and 
intentions, and the ways it affects employee behaviour to establish effective ways to install rewards and recognition systems motivating employee participation in CI projects. The present research corroborates findings of the previous studies on the need to implement both soft and hard practices to achieve comprehensive performance of CI initiatives ( Shah \& Ward, 2003; Pont et al., 2009; Wickramasinghe \& Wickramasinghe, 2011 Hadid et al., 2016). The results of the conducted study are suitable for further generalization and a practical application in organizations, since the developed model demonstrates a high fit. The research findings can serve as a reference point for the organizations, implementing CI programs in the areas of organizational practices and infrastructure that can potentially lead to the higher level of cost reduction attainment. The study confirms varying impact of organizational practices the ability of CI to reduce cost reduction.

One of the advantages of the present study is its focus on studying application of $\mathrm{CI}$ in the services in order to contribute to the lessstudied field of CI in the non-manufacturing processes. The methodological approach of a focus on a specific industry was adapted based on Hietschold et al. (2014) with a goal to ensure high relevance of the study results for application in the practical settings. However, the focus of the research on a single industry could also be considered as a limitation of the study and more research could contribute to the exploration of the differences in CI practices in different industries and organizations.

Another limitation of the study is related to the selected dependent variable of Cost Reduction. Methodologically, the selection of the Cost Reduction as a major performance measure for $\mathrm{CI}$ is based on the seminal works on operations management by Deming (1986), Imai (1986), and Liker and Morgan (2006). However, further studies could explore a range of other firm performance measures (e.g financial, quality, customer satisfaction, innovation, etc.). One more limitation of the study is inherent to the operationalization of the mediator variables through the single items (Fuchs \& Diamantopoulos, 2009). This limitation could be addressed in the future research by exploring a broader set of survey items. Further, the use of the survey as a major way of data collection may lead to the data containing certain bias. Lastly, the data for the research was collected at a single point of time. However, evolutionary theory of CI by Bessant et al. (2001) suggest the need for longitudinal study of CI phenomenon within services industry to complement and expand the research results by providing insights on the dynamics of the CI-firm performance relationship, proposed in the research, over time.

\section{CONCLUSIONS}

In the face of growing importance of services industry globally, the question of the efficiency of service operations receives an increased attention in the academic and professional literature. The specifics of service operations lead to the comparably low efficiency and increased complexity induced by the need to adapt to customer needs. However, the research on the improvement of service operations is comparably scarce. Since cost reduction is one of the major motives for introduction of CI, the goal of the proposed research was to evaluate effect of Continuous Improvement on Cost Reduction and to further investigate 
which practices have the ability to positively impact CI - Cost Reduction relationship.

As the first step in the study, a preliminary model describing CI - Cost reduction relationship was established. Based on the literature review it was hypothesised that the following practices are able to facilitate cost reduction through $\mathrm{CI}$ in the organizations: rewards, management commitment, training, quality culture and goal setting. To analyze the proposed priori model, the data was collected through the survey. In total, 304 responses were analyzed with the structural equation modeling to test the initial hypotheses.

One of the main findings of the study suggests that implementation of continuous improvement initiative without development of the supporting infrastructure may not lead to the achievement of cost reduction benefits. Consequently, if the company implements CI initiative with a sole purpose of cost reduction, it is recommended to supplement CI implementation with the development of the supporting infrastructure in the form of implementation of the following organizational practices: development of rewards and recognition system of employees participating in improvement initiative, instilment of quality culture, provision of training on improvement methodologies to employees as well as establishment of the goal setting system for the improvement projects. Another interesting finding is related to the role of management commitment in attainment of cost reduction benefits. The analysis demonstrates that management commitment could have a negative impact on $\mathrm{CI}$ - cost reduction relationship; thus, more research is needed to establish the levels and forms of management involvement in CI process that would ensure cost reduction. The research findings provide guidelines for companies that implement continuous improvement initiative on the ways to achieve cost reduction benefits. Furthermore, the research provides recommendations on the investment allocation and management of CI initiatives in the services environment by providing insights on the required infrastructure for $\mathrm{CI}$ effectiveness.

In terms of academic insights, the study provides several important findings for further research in the area of CI performance improvement. First, by contributing to understanding of the impact of CI on firm performance as well as by providing insights on the necessary prerequisites for $\mathrm{CI}$ effectiveness in the services industry. Second, by challenging the well-established notion of the role of management commitment for CI effectiveness. More research is needed to identify the ways and forms of management involvement in CI process that would ensure the desired level of CI performance. Third, by providing further insights on the role of rewards and goal setting for effectiveness of CI. The research contributes to an ongoing scientific debate on employee motivation and further confirms the need for the research on the ways to engage and motivate employees through the goals and rewards to participate in improvement initiatives.

\section{Acknowledgements}

We would like to thank the Internal Grant Agency of Tomas Bata University in Zlin (grant number IGA/FAME/2017/008 and IGA/FAME/2018/005) as well as the Visegrad Fund (grant number 51700045) for financial support. A special thanks goes to Nikita Nikitin from WebKr Gmbh. for the technical support of data collection. 


\section{References}

Anand, G., Chhajed, D., \& Delfin, L. (2012). Job autonomy, trust in leadership, and continuous improvement: An empirical study in health care. Operations Management Research, 5(3-4), 70-80.

Ashkenas, R. (2012). It's Time to Rethink Continuous Improvement. Retrieved May 13, 2017, from https://hbr.org/2012/05/itstime-to-rethink-continuous

Baron, R.M., \& Kenny, D.A. (1986). The Moderator-Mediator Variable Distinction in Social Psychological Research: Conceptual, Strategic, and Statistical Considerations. Journal of Personality and Social Psychology, 51(6), 1173-1182.

Bessant, J., Caffyn, S., \& Gallagher, M. (2001). An evolutionary model of continuous improvement behaviour. Technovation, 21(2), 67-77.

Bon, A.T., \& Mustafa, E.M.A. (2013). Impact of total quality management on innovation in service organizations: Literature review and new conceptual framework. Procedia Engineering. Elsevier B.V., 53, 516- 529.

Bortolotti, T., Boscari, S., \& Danese, P. (2015). Successful lean implementation: Organizational culture and soft lean practices. International Journal of Production Economics, 160(February), 182-201.

Chakravorty, S.S. (2009). Six Sigma programs: An implementation model. International Journal of Production Economics, 119(1), 1-16.

D’Andreamatteo, A., Ianni, L., Lega, F., \& Sargiacomo, M. (2015). Lean in healthcare: A comprehensive review. Health Policy, 119(9), 1197-1209.

Delgado, C., Ferreira, M., \& Castelo Branco, M. (2010). The implementation of lean Six Sigma in financial services organizations. Journal of Manufacturing Technology Management, 21(4), 512-523.

Deming, W. E. (1986) Out of the Crisis. Cambridge, MA: MIT Center for Advanced Engineering Study.

Deming, W. E. (1993). The New Economics for Industry, Government, Education (2nd ed.). Cambridge, MA: Mit University Press Group Ltd.

Detert, J. R., Schroeder, R. G., \& Mauriel, J. J. (2000). A framework for linking culture and improvement initiatives in organizations. Academy of Management Review, 25(4), 850-863.

Dubey, R., Singh, T., \& Ali, S.S. (2015). The mediating effect of human resource on successful total quality management implementation: An empirical study on SMEs in manufacturing sectors. Benchmarking: An International Journal, 22(7), 1463-1480.

Edmondson, A.C., \& McManus, S.E. (2007). Methological fit in management field research. Academy of Management Review, 32(4), 1155-1179.

Fuchs, C., \& Diamantopoulos, A. (2009). Using single-item measures for construct measurement in management research: Conceptual issues and application guidelines. Die Betriebswirtschaft, 69(2), 195-211.

Galeazzo, A., Furlan, A., \& Vinelli, A. (2016). The organizational infrastructure of continuous improvement - an empirical analysis. Operations Management Research, 10 (1-2), 33-46.

George, M. L. (2003). Lean Six Sigma for Service: How to Use Lean Speed and Six Sigma Quality to Improve Services and Transactions. New York: McGraw-Hill.

Graban, M., \& Swartz, J. E. (2012). Healthcare Kaizen: Engaging Front-Line Staff in Sustainable Continuous 


\title{
КОНТИНУИРАНО ПОБОЉШАЊЕ И ОРГАНИЗАЦИОНЕ ПРАКСЕ У СЕРВИСИРАНИМ ФИРМАМА: ИСТРАЖИВАЫЕ УТИЦАЈА НА СМАЫЕЊЕ ТРОШКОВА
}

\author{
Oksana Koval, Stephen Nabareseh, Roland Stankalla, Felicita Chromjakova ${ }^{a}$
}

\section{Извод}

Све већи значај услужних сектора за глобалну трговину узрокује питање како се борити против урођене сложености и неефикасности услуга. Као одговор на растуће захтеве за побољшањем ефикасности услуга, компаније имплементирају иницијативе континуираног побољшања (КП) како би смањиле трошкове пословања. Међутим, истраживачи нису успели да постигну консензус о ефекту ефикасности КП операција у непроизводном окружењу. Стога, предложена студија покушава да одговори на важно питање утицаја КП на смањење трошкова у услужном окружењу применом модела структурних једначина (МСЈ) на 304 одговора из анкете прикупљених током истраживања. Осим тога, истраживање анализира како организациона пракса утиче на однос између КП и смањења трошкова. Студија сугерише да сама КП није у стању да смањи трошкове и захтева подршку вишеструких организационих пракси, као што су награде и признавања запосленима, култура квалитета, обука запослених и постављање циљева, како би се добиле користи од смањења трошкова. Сходно томе, резултати истраживања омогућују закључак са огромним практичним импликацијама, а то је да постоји потреба за развојем свеобухватне инфраструктуре организационих пракси за подршку ЦП како би се постигло смањење трошкова. Налази истраживања дају препоруке за имплементацију КП и приоритетизацију улагања у услужним организацијама.

Кључне речи: континуирано усавршавање, услужне компаније, смањење трошкова, МСJ, B4 земље

Improvements. Taylor \& Francis.

Habtoor, N. (2016). Influence of human factors on organisational performance: quality improvement practices as a mediator variable. International Journal of Productivity and Performance Management, 65(4), 460-484.

Hadid, W., Mansouri, A., \& Gallear, D. (2016). Is lean service promising? A sociotechnical perspective. International Journal of Operations \& Production Management, 36(6), 618-642.

Hair, J.F., Tatham, R.L., Anderson, R.E., \& Black, W. (1998). Multivariate Data Analysis, 5th Edition. Prentice Hall
Hendricks, K.B., \& Singhal, V.R. (2001). Firm characteristics, total quality management, and financial performance. Journal of Operations Management, 19(3), 269-285.

Hietschold, N., Reinhardt, R., \& Gurtner, S. (2014). Measuring critical success factors of TQM implementation successfully - a systematic literature review. International Journal of Production Research, 52(21), 6254-6272.

Iacobucci, D., Saldanha, N., \& Deng, X. (2007). A mediation on mediation: Evidence that structural equation models perform better than regression. Journal of Consumer 
Psychological, 7(2), 140-154.

Imai, M. (1986). Kaizen: The Key to Japan's Competitive Success. McGraw-Hill Education, New York.

Jayanth, J., \& Xu, K. (2016). Determinants of Quality and Efficiency Performance in Service Operations. International Journal of Operations \& Production Management, 36(3), 265-285.

Jurburg, D., Viles, E., Jaca, C., \& Tanco, M. (2015). Why are companies still struggling to reach higher continuous improvement maturity levels? Empirical evidence from high performance companies. TQM Journal, 27(3), 316-327.

Kaynak, H. (2003). The relationship between total quality management practices and their effects on firm performance. Journal of Operations Management, 21(4), 405-435.

Liker, J.K., \& Morgan, J.M. (2006). The Toyota Way in Services: The Case of Lean Product Development. Academy of Management Perspectives, 20(2), 5-20.

McFadden, K.L., Lee, J. Y., Gowen III, C. R., \& Sharp, B. M. (2014). Linking quality improvement practices to knowledge management capabilities. Quality Management Journal, 21(1), 42-58.

Milner, C.D., \& Savage, B.M. (2016). Modeling continuous improvement evolution in the service sector. International Journal of Quality and Service Sciences, 8(3), 438-460.

Näslund, D. (2013). Lean and six sigma critical success factors revisited. International Journal of Quality and Service Sciences, 5(1), 86-100.

Paagman, A., Tate, M., Furtmueller, E., \& de Bloom, J. (2015). An integrative literature review and empirical validation of motives for introducing shared services in government organizations. International
Journal of Information Management, 35(1), 110-123.

Pellicer, E., Yepes, V., Correa, C.L., \& Alarcón, L.F. (2012). Organizational improvement through standardization of the innovation process in construction firms. EMJ - Engineering Management Journal, 24(2), 40-53.

Peng, D.X., Schroeder, R.G., \& Shah, R. (2008). Linking routines to operations capabilities: A new perspective. Journal of Operations Management, 26(6), 730-748.

Piercy, N., \& Rich, N. (2009). High quality and low cost: the lean service centre. European Journal of Marketing, 43(11/12), 1477-1497.

Pont, G.D., Furlan, A., \& Vinelli, A. (2009). Interrelationships among lean bundles and their effects on operational performance. Operations Management Research, 1(2), 150-158.

Powell, T.C. (1995). Total Quality Management as competitive advantage: a review and Empirical study. Strategic Management Journal, 16(1), 15-37.

Prajogo, D. I., \& Brown, A. (2006). Approaches to adopting quality in SMEs and the impact on quality management practices and performance. Total Quality Management \& Business Excellence, 17(5), 555-566.

Romero, H.L., Dijkman, R.M., Grefen, P.W.P.J., \& Van Weele, A.J. (2015). Factors that Determine the Extent of Business Process Standardization and the Subsequent Effect on Business Performance. Business and Information Systems Engineering, 57(4), 261-270.

Rust, R.T., Moorman, C., \& Dickson, P.R. (2002). Getting Return on Quality: Revenue Expansion, Cost Reduction, or Both? Journal of Marketing, 66(4), 7-24.

Sabella, A., Kashou, R., \& Omran, O. (2014). Quality management practices and 
their relationship to organizational performance. International Journal of Operations \& Production Management, 34(12), 1487-1505.

Shah, R., \& Goldstein, S.M. (2006). Use of structural equation modeling in operations management research: Looking back and forward. Journal of Operations Management, 24(2), 148-169.

Shah, R., \& Ward, P.T. (2003). Lean manufacturing: Context, practice bundles, and performance. Journal of Operations Management, 21(2), 129-149.

Sila, I. (2007). Examining the effects of contextual factors on TQM and performance through the lens of organizational theories: An empirical study. Journal of Operations Management, 25(1), 83-109.

Swartling, D., \& Poksinska, B. (2013). Management Initiation of Continuous Improvement from a Motivational Perspective. Journal of Applied Economics and Business Research, 3(2), 81-94.

Taylor, A., Taylor, M., \& McSweeney, A. (2013). Towards greater understanding of success and survival of lean systems. International Journal of Production Research, 51(22), 6607-6630.

Wickramasinghe, D., \& Wickramasinghe, V. (2011). Differences in Organizational Factors by Lean Duration. Operations Management Research, 4(3-4), 111-126.

Williams, C. A. (2006). Advancing federal financial management. The Journal of Government Financial Management, 55(4), 52-57.

Yang, Y., Lee, P.K.C., \& Cheng, T.C.E. (2014). Continuous improvement competence, employee creativity, and new service development performance: A frontline employee perspective. International Journal of Production Economics, 171(Part 2), 275-288. 